\title{
PENCAPAIAN KEMAMPUAN PEMECAHAN MASALAH MATEMATIKA SISWA KELAS VIII DALAM KOMPETENSI DASAR GEOMETRI KELAS VII DI SMP/MTS KECAMATAN SAMBUTAN TAHUN AJARAN 2015/2016
}

\author{
Nuuri Hanifah ${ }^{1),(*)}$ \\ P.M. Labulan ${ }^{2)}$ \\ Kukuh ${ }^{3)}$ \\ 1), Mahasiswa Program Studi Pendidikan Matematika \\ 2), 3) Dosen Program Studi Pendidikan Matematika, Universitas Mulawarman \\ Email: ${ }^{(*)}$ hanifahbentsoe@gmail.com
}

\begin{abstract}
ABSTRAK
Penelitian ini bersifat deskriptif kuantitatif bertujuan untuk memberikan informasi mengenai tingkat pencapaian kemampuan pemecahan masalah pada kompetensi dasar materi geometri kelas VII pada siswa kelas VIII di SMP/MTS Kecamatan Sambutan. Subjek penelitian yaitu siswa kelas VIII SMP/MTS di Kecamatan Sambutan. SMPN 9 diambil 4 kelas yaitu VIIIC, VIIIG, VIIIH, dan VIIIF. MTS Nurul Islam diambil 1 kelas. MTS Al Misra diambil 1 kelas.. SMPN 17 diambil 2 kelas yaitu VIIIE dan VIIIF. SMPN 41 diambil 1 kelas yaitu VIIIF. SMPN 23 diambil 1 kelas yaitu VIIIC. Objek penelitian adalah kemampuan pemecahan masalah siswa kelas VIII dalam kompetensi dasar materi geometri kelas VII. Penelitian ini dilaksanakan pada bulan April-Mei 2016 dengan jumlah responden sebanyak 270 siswa. Pengumpulan data menggunakan tes tertulis berupa soal uraian sebanyak 5 butir. Uji coba diadakan di SMP Negeri 9 Samarinda yaitu di kelas VIIIC untuk mengetahui kualitas instrument soal dianalisis menggunakan realibilitas, indeks kesukaran dan indeks pembeda. Berdasarkan hasil analisis deskriptif diperoleh tingkat kemampuan pemecahan masalah pada kompetensi dasar materi geometri kelas VII pada siswa kelas VIII SMP/MTS di Kecamatan Sambutan sebesar 29,49\% dengan persentase masing-masing aspek kemampuan pemecahan masalah: Kemampuan mengidentifikasi masalah sebesar 29,63\% dengan kategori rendah, kemampuan merencanakan penyelesaian masalah sebesar 28,33\% dengan kategori rendah, kemampuan menyelesaikan masalah sebesar 29,74\% dengan kategori rendah, kemampuan menginterpretasikan hasil sebesar 30,27\% dengan kategori rendah. Berdasarkan hasil analisis, dapat disimpulkan bahwa tingkat kemampuan pemecahan masalah pada kompetensi dasar materi geometri kelas VII pada siswa kelas VIII SMP/MTS di Kecamatan Sambutan memiliki kategori rendah.
\end{abstract}

Kata kunci: Kemampuan Pemecahan Masalah, Kompetensi Dasar, Statistik Deskriptif. 


\begin{abstract}
This study is descriptive quantitative aims to provide information about the level of achievement of problem-solving skills on the basic competence of class VII geometry materials in grade VIII students in SMP / MTS Sambutan District. The subjects of the study were VIII SMP / MTS students in Kecamatan Sambutan. From SMPN 9, the researcher chooses 4 classes VIIIC, VIIIG, VIIIH, and VIIIF. From MTS Nurul Islam and MTS Al Misra 1 Class for each. There are 2 classes from SMPN 17, VIIIE dan VIIIF.There is 1 class from SMPN 41, and 1 Class from SMPN 23. The object of the research is the problem solving ability of class VIII students in the basic competence of class VII geometry material. This research was conducted in April-May 2016 with the number of respondents as many as 270 students. Data collection is using a written test in the form of a description of 5 items. The trials were held at SMP Negeri 9 Samarinda in class VIIIC to know the quality of the analyzed instrument using the reliability, difficulty index and differentiation index. Based on the results of descriptive analysis, obtained the level of problem solving skills on the basic competence of class VII geometry materials in VIII grade SMP/MTS students in Sambutan Districs by $29.49 \%$ with percentage of each aspect of problem solving ability: Ability to identify problems of $29.63 \%$ with low category, ability to plan problem solving $28.33 \%$ with low category, problem solving ability $29,74 \%$ with low category, ability to interpret result $30,27 \%$ with low category. Based on the results of the analysis, it can be concluded that the level of problem-solving skills on the basic competence of class VII geometry materials in grade VIII SMP / MTS students in Kecamatan Sambutan have low category.
\end{abstract}

Keywords: Problem solving abilities, Basic competency, Statistic descriptif

\section{PENDAHULUAN}

Pendidikan adalah usaha sadar untuk menyiapkan siswa melalui kegiatan bimbingan, pengajaran, dan latihan bagi peranannya di masa yang akan datang. Maka tantangan sebagai seorang pendidik ialah menyiapkan siswa untuk hidup di masa depan, bukan semata-mata dalam lingkungan saat ini. Pendidik menyiapkan seseorang untuk hidup dalam lingkungan yang sebagian besar belum dikenal disebabkan oleh adanya akselerasi yang luar biasa dari perubahan-perubahan yang terjadi saat ini, yaitu era globalisasi.

Perkembangan matematika dari tahun ke tahun terus meningkat sesuai dengan tuntutan zaman. Karena tuntutan zaman itulah yang mendorong manusia untuk lebih kreatif dalam mengembangkan atau menerapkan matematika sebagai ilmu dasar. Salah satu pengembangan yang dimaksud adalah masalah pembelajaran matematika. Melalui pembelajaran matematika, siswa diharapkan dapat menumbuhkan kemampuan berpikir kritis, logis, sistematis, cermat, efektif, dan efisien dalam memecahkan masalah. Tercapai atau tidaknya tujuan pendidikan dan pembelajaran matematika salah satunya dapat dinilai dari keberhasilan siswa dalam memahami matematika dan memanfaatkan pemahaman ini untuk menyelesaikan persoalan-persoalan matematika maupun ilmu-ilmu yang lain di dalam kelas maupun diluar kelas. 
Sasaran dalam pembelajaran matematika saat ini adalah mendorong siswa untuk menerapkan matematika pada pemecahan-pemecahan masalah dan penyelidikan, karena di masa depan siswa tidak hanya dinilai berdasarkan kemampuan mereka dalam mengerjakan perhitungan namun juga kemampuan untuk menggunakan dan menerapkan matematika.

Kemampuan pemecahan masalah merupakan salah satu komponen penting dalam pembelajaran matematika yang harus dikuasai dan dikembangkan. Salah satu materi pembelajaran yang melatih kemampuan pemecahan masalah adalah geometri. Geometri dapat muncul untuk menjawab persoalan manusia dikehidupan nyata. Geometri memiliki posisi yang strategis untuk mengembangkan kemampuan pemecahan masalah siswa. Geometri dianggap mempunyai banyak aplikasi dalam matematika dan kehidupan nyata, yang banyak mengandung unsur problem solving. Geometri telah diajarkan sejak SD, namun ternyata kemampuan siswa dalam menyelesaikan soal dimensi tiga masih rendah (Suwaji, 2008:1). Materi geometri merupakan salah satu materi yang dipelajari pada tingkat Sekolah Menengah Pertama (SMP).

Berdasarkan penelitian yang pernah dilakukan di berbagai tempat, banyak siswa yang cenderung menghafalkan konsep-konsep matematika tanpa memahami maksud isinya. Pada umumnya siswa hanya mengikuti contoh soal yang diberikan oleh guru atau buku. Juga terdapat siswa yang bermalasmalasan saja tidak mau mencari sendiri ide-idenya hanya guru yang berperan aktif dalam proses belajar mengajar. Hal ini menunjukkan bahwa kemampuan pemecahan masalah sebagian besar siswa masih sangat kurang disebabkan lemahnya kemampuan pemahaman konsep yang dimiliki. Hal inilah yang mendasari penelitian ini dilakukan untuk mendeskripsikan kemampuan pemecahan masalah matematika siswa. Diharapkan dengan mengetahui tingkat kemampuan pemecahan masalah siswa dapat membantu guru dalam menyusun strategi pembelajaran untuk meningkatkan kemampuan pemecahan masalah siswa.

Kecamatan Sambutan menjadi daya tarik tersendiri bagi peneliti sebab kecamatan sambutan kurang menjadi sorotan dalam penelitian pendidikan. Di kecamatan sambutan terdapat 6 SMP baik negeri maupun swasta. Harapan ke depannya setelah mengetahui kemampuan siswa SMP di kecamatan sambutan, ada tindak lanjut dari penelitian ini, seperti upaya-upaya peningkatan kemampuan baik melalui usaha guru secara langsung atau melalui mahasiswa penelitian.

\section{METODE PENELITIAN}

Jenis penelitian ini adalah deskriptif dengan pendekatan kuantitatif. Asmani (2011:40) menyatakan bahwa penelitian deskriptif adalah penelitian yang berusaha mendeskripsikan suatu gejala, peristiwa, kejadian yang terjadi saat sekarang tanpa memberikan perlakuan khusus terhadap peristiwa tersebut.

Jenis data yang diambil dalam penelitian ini berupa data berbentuk angka, hasil perhitungan dan pengukuran pekerjaan siswa dalam menyelesaikan soal. Selanjutnya data dianalisis, 
diinterpretasikan, dan diklasifikasikan ke dalam katagori baik sekali, baik, cukup, kurang, dan kurang sekali. Kemampuan yang dimiliki siswa dinyatakan dalam persentase, untuk kemudian dideskripsikan sehingga dapat ditarik kesimpulan dari penelitian ini. Penelitian ini dilaksanakan pada Agustus 2015 di kelas VIII SMP/MTS Kecamatan Sambutan tahun ajaran 2014/2015. SMP/MTs di kecamatan Sambutan adalah SMP N 9, SMP N 23, SMP N 17, SMP N 41, MTS Al-Misra, dan MTS Nurul Islam.

Adapun langkah-langkah dalam penentuan sampei dalam penelitian ini sebagai berikut:

1. Peneliti memilih 6 SMP/MTS yang berada di Kecamatan Sambutan menjadi sampel. Adapun sekolah di Kecamatan Sambutan yang digunakan sebagai sampel penelitian adalah SMP Negeri 9 Samarinda, SMP Negeri 17 Samarinda, SMP Negeri 23 Samarinda, SMP Negeri 41 Samarinda, dan MTS Al Misra dan MTS Nurul Islam

2. Diambil beberapa kelas dari masingmasing sekolah secara acak untuk dijadikan sampel sesuai dengan jumlah sampel yang sudah dihitung.

3. Dengan menggunakan metode pengambilan sampel Proportional Random Sampling yaitu pengambilan anggota sampel dari anggota populasi secara acak, berkelompok, dan proporsional dengan perhitungan sebagai berikut

$$
X_{i}=\frac{N_{i}}{N} S
$$

dimana $X_{i}$ adalah jumlah sampel kelas berdasarkan sekolah, $N_{i}$ adalah jumlah populasi kelas berdasarkan sekolah, $N$ adalah jumlah populasi kelas seluruh sekolah, dan $S$ adalah jumlah sampel kelas seluruh sekolah. Dari rumus tersebut, diperoleh sampel penelitian seperti pada Tabel 1 berikut.

Tabel 1. Sampel Penelitian

\begin{tabular}{|l|c|c|}
\hline Nama Sekolah & $\begin{array}{l}\text { Banyak } \\
\text { Kelas }\end{array}$ & $\begin{array}{l}\text { Banyak } \\
\text { Siswa }\end{array}$ \\
\hline SMPN 9 Samarinda & 3 & 99 \\
\hline SMPN 17 Samarinda & 2 & 60 \\
\hline SMPN 41 Samarinda & 1 & 18 \\
\hline SMPN 23 Makroman & 1 & 30 \\
\hline $\begin{array}{l}\text { MTs Al Misra } \\
\text { Samarinda }\end{array}$ & 1 & 30 \\
\hline $\begin{array}{l}\text { MTs Nurul Islam } \\
\text { Samarinda }\end{array}$ & 1 & 26 \\
\hline Jumlah Instrumen yang digunakan
\end{tabular}

penelitian ini berupa tes tertulis dalam bentuk soal uraian. Adapun langkahlangkah untuk menganalisis data yaitu sebagai berikut:

a. Menentukan skor yang diperoleh masing-masing siswa kelas VIII SMP/MTS di Kecamatan Sambutan.

b. Menentukan persentase tiap indikator kemampuan pemecahan masalah.

Berikut indikator kemampuan pemecahan masalah menurut Kesumawati (Chotimah, 2014) dijabarkan, yaitu:

$\mathrm{A}=$ Mengidentifikasi masalah

1. Mengidentifikasi informasi yang diketahui dari soal

2. Mengidentifikasi apa yang ditanyakan dari soal

$\mathrm{B}=$ Menyusun model pemecahan masalah 
1. Menentukan cara pemecahan yang sesuai

2. Menggunakan informasi yang diketahui untuk memperoleh informasi baru.

$\mathrm{C}=$ Memilih Strategi Pemecahan Masalah

1. Mensubtitusi nilai yang diketahui dalam cara pemecahan masalah yang digunakan

2. Menghitung pemecahan masalah $\mathrm{D}=$ Sinkron hasil

\section{HASIL PENELITIAN DAN PEMBA-}

\section{HASAN}

Persentase tingkat kemampuan pemecahan masalah tiap kompetensi pada siswa kelas VIII dari sampel subjek penelitian sebanyak 270 siswa kelas VIII di 6 (enam) SMP/MTS Kecamatan Sambutan terdapat pada tabel berikut.

Tabel 3. Presentase rata-rata tingkat kemampuan Pemecahan Masalah SMP/MTS Per kelas sampel di Kecamatan Sambutan.

\begin{tabular}{|l|l|l|l|}
\hline $\begin{array}{l}\text { Nama } \\
\text { Sekolah }\end{array}$ & Kelas & Rerata & Kategori \\
\hline SMPN 9 & VIII $_{\mathrm{C}}$ & $47,08 \%$ & Cukup \\
\hline SMPN 9 & VIII $_{\mathrm{G}}$ & $44,15 \%$ & Cukup \\
\hline SMPN 9 & VIII $_{\mathrm{H}}$ & $48,48 \%$ & Cukup \\
\hline $\begin{array}{l}\text { MTs } \\
\text { Nurul } \\
\text { Islam }\end{array}$ & VIII & $21,74 \%$ & Rendah \\
\hline $\begin{array}{l}\text { MTs Al } \\
\text { Misra }\end{array}$ & VIII $_{\mathrm{C}}$ & $23,43 \%$ & Rendah \\
\hline SMPN 17 & VIII $_{\mathrm{E}}$ & $29,06 \%$ & Rendah \\
\hline SMPN 17 & VIII $_{\mathrm{F}}$ & $25,80 \%$ & Rendah \\
\hline SMPN 41 & VIII $_{\mathrm{F}}$ & $24,43 \%$ & Rendah \\
\hline SMPN 23 & VIII $_{\mathrm{C}}$ & $37,70 \%$ & Rendah \\
\hline
\end{tabular}

Pencapaian Kemampuan Pemecahan Masalah Matematika Siswa Kelas VIII Dalam Kompetensi Dasar Geometri Kelas VII Di SMP/MTs Kecamatan Sambutan Tahun Ajaran 2015/2016 Nuuri Hanifah - P.M. Labulan - Kukuh
Tabel 4. Presentase rata-rata tingkat kemampuan Pemecahan Masalah SMP/MTS Per sekolah di Kecamatan Sambutan

\begin{tabular}{|c|c|c|c|c|}
\hline $\begin{array}{l}\text { Nama } \\
\text { Sekolah }\end{array}$ & $\begin{array}{l}\text { Rata- } \\
\text { rata }\end{array}$ & Ketegori & $\begin{array}{l}\text { Rata-rata } \\
\text { keseluruh } \\
\text { an Siswa }\end{array}$ & Kategori \\
\hline SMPN 9 & $\begin{array}{l}40,4 \\
\% \\
\end{array}$ & Cukup & \multirow[t]{6}{*}{$29,49 \%$} & \multirow[t]{6}{*}{ Rendah } \\
\hline $\begin{array}{l}\text { MTs } \\
\text { Nurul } \\
\text { Islam }\end{array}$ & $\begin{array}{l}23,6 \\
\%\end{array}$ & Rendah & & \\
\hline $\begin{array}{l}\text { MTs Al } \\
\text { Misra }\end{array}$ & $\begin{array}{l}23,4 \\
\% \\
\end{array}$ & Rendah & & \\
\hline $\begin{array}{l}\text { SMPN } \\
17\end{array}$ & $\begin{array}{l}27,4 \\
\%\end{array}$ & Rendah & & \\
\hline $\begin{array}{l}\text { SMPN } \\
41\end{array}$ & $\begin{array}{l}24,4 \\
\% \\
\end{array}$ & Rendah & & \\
\hline $\begin{array}{l}\text { SMPN } \\
23\end{array}$ & $\begin{array}{l}37,7 \\
\%\end{array}$ & Rendah & & \\
\hline
\end{tabular}

Dari Tabel 4, terlihat bahwa di antara 6 (enam) sekolah SMP/MTS di Kecamatan Sambutan memiliki rata-rata pencapaian kemampuan masalah rendah dengan persentase 24,49\%. Meskipun SMP/MTS di kecamatan Sambutan memiliki pencapaian kemampuan masalah matematika rendah, siswa di SMP $\mathrm{N} 9$ Samarinda memiliki pencapaian kemampuan masalah matematika cukup dengan perentase $40,36 \%$.

Persentase tingkat kemampuan pemecahan masalah tiap kompetensi pada siswa kelas VIII dari sampel subjek penelitian sebanyak 270 siswa kelas VIII di SMP/MTS Kecamatan Sambutan terdapat pada Tabel 5. 
Tabel 5. Persentase Kemampuan Pemecahan Masalah Matematika Siswa Kelas VII dalam Kompetensi Dasar Geometri Kelas VII

\begin{tabular}{|c|c|c|c|c|}
\hline No. & Kompetensi Dasar & Indikator & VIII & Kategori \\
\hline 1 & $\begin{array}{l}\text { Mengidentifikasi sifat-sifat segi } \\
\text { empat, segitiga, sudutdan garis }\end{array}$ & $\begin{array}{l}\text { Menentukan benar salah } \\
\text { dari suatu pernyataan }\end{array}$ & $34 \%$ & Rendah \\
\hline 2 & $\begin{array}{l}\text { Memahami dan menentukan } \\
\text { hubungan dua garis, besar dan jenis } \\
\text { sudut }\end{array}$ & $\begin{array}{l}\text { Menentukan besar sudut } \mathrm{x} \\
\text { dengan diketahui besar } \\
\text { sudut di sekelilingnya }\end{array}$ & $62 \%$ & Tinggi \\
\hline 3 & $\begin{array}{l}\text { Menghitung keliling dan luas } \\
\text { bangun segitiga dan segi empat } \\
\text { serta menggunakannya dalam } \\
\text { pemecahan masalah }\end{array}$ & $\begin{array}{l}\text { Menentukan luas } \\
\text { gabungan beberapa bidang } \\
\text { segi empat }\end{array}$ & $8 \%$ & $\begin{array}{l}\text { Sangat } \\
\text { Rendah }\end{array}$ \\
\hline 4 & $\begin{array}{l}\text { Memahami sifat-sifat sudut yang } \\
\text { terbentuk jika dua garis } \\
\text { berpotongan atau dua garis sejajar } \\
\text { berpotongan dengan garis lain }\end{array}$ & $\begin{array}{l}\text { Menentukan besar } r \text { sudut } \\
\text { pada gambar dengan } \\
\text { diketahui besar sudut } \\
\text { pelurusnya }\end{array}$ & $49 \%$ & Cukup \\
\hline 5 & $\begin{array}{l}\text { Menghitung keliling dan luas } \\
\text { bangun segitiga dan segi empat } \\
\text { serta menggunakannya dalam } \\
\text { pemecahan masalah. }\end{array}$ & $\begin{array}{l}\text { Menentukan keliling } \\
\text { segitiga }\end{array}$ & $10 \%$ & $\begin{array}{l}\text { Sangat } \\
\text { Rendah }\end{array}$ \\
\hline
\end{tabular}

Berdasarkan Tabel 5, terlihat bahwa tingkat kemampuan pemecahan masalah dalam kompetensi mengidentifikasi sifatsifat segi empat, segitiga, sudut dan garis memiliki persentase $34 \%$ dengan kategori rendah. Hal ini disebabkan siswa kurang mampu menentukan benar salah dari suatu pernyataan berkaitan dengan sifatsifat segi empat, segitiga, sudut, dan garis.

Tingkat kemampuan pemecahan masalah dalam kompetensi memahami dan menentukan hubungan dua garis, besar dan jenis sudut memiliki persentase $62 \%$ dengan kategori tinggi. Hal ini disebabkan siswa mampu dalam menentukan besar sudut yang ditanyakan dengan diketahui besar sudut di sekitarnya.

Tingkat kemampuan pemecahan masalah dalam kompetensi menghitung keliling dan luas bangun segitiga dan segi empat serta menggunakannya dalam pemecahan masalah memiliki persentase
9\% dengan kategori sangat rendah. Hal ini disebabkan siswa kurang mampu dalam menentukan luas gabungan beberapa bidang segi empat dan menentukan keliling segitiga.

Tingkat kemampuan pemecahan masalah dalam kompetensi memahami sifat-sifat sudut yang terbentuk jika dua garis berpotongan atau dua garis sejajar berpotongan dengan garis lain memiliki persentase $49 \%$ dengan kategori cukup. Hal ini disebabkan siswa cukup mampu menentukan besar sudut pada gambar dengan diketahui besar sudut pelurusnya.

Tingkat kemampuan pemecahan masalah dalam penelitian ini ditentukan dari skor yang diperoleh siswa yang selanjutnya diolah menjadi persentase sehingga dapat diketahui tingkat kemampuan pemecahan masalahnya. Untuk tingkat kemampuan pemecahan masalah matematika dari tiap indikator kemampuan pemecahan masalah pada

76 Pencapaian Kemampuan Pemecahan Masalah Matematika Siswa Kelas VIII Dalam Kompetensi Dasar Geometri Kelas VII Di SMP/MTs Kecamatan Sambutan Tahun Ajaran 2015/2016

Nuuri Hanifah - P.M. Labulan - Kukuh 
tiap kompetensi dapat diketahui sebagai berikut:

\section{Kompetensi Mengidentifikasi Sifat- Sifat Segi Empat, Segitiga, dan Garis}

Untuk kompetensi ini terdapat pada instrumen nomor 1 diperoleh persentase tingkat pemecahan masalah dengan indikator mengidentifikasi masalah dari instrumen sebesar 33,5\% dengan kategori rendah. Dari persentase ini terlihat bahwa secara keseluruhan siswa kelas VIII SMP/MTs Kecamatan Sambutan memiliki tingkat kemampuan pemecahan masalah rendah dalam mengidentifikasi informasi yang diketahui dari instrument tes dan mengidentifikasi apa yang ditanyakan dari instrument tes.

\section{Kompetensi Memahami dan} Menentukan Hubungan Dua Garis, Besar, dan Jenis Sudut

Untuk kompetensi ini terdapat pada instrumen tes nomor 2. Pada instrumen instrumen nomor 2 diperoleh persentase dari kompetensi ini yaitu sebesar $66,85 \%$ dengan kategori tinggi. Dari persentase ini terlihat bahwa secara keseluruhan siswa kelas VIII SMP/ MTS Kecamatan Sambutan tingkat kemampuan pemecahan masalah tinggi dalam memahami dan menentukan hubungan dua garis, besar dan jenis sudut.

\section{Kompetensi Menghitung Keliling} dan Luas Bangun Segitiga dan Segi Empat serta Menggunakannya dalam Pemecahan Masalah

Untuk kompetensi ini terdapat pada instrument penelitian nomor 3 dan 5. Pada instrument instrumen nomor 3 diperoleh persentase untuk kompetensi ini yaitu sebesar 3,46\% dengan kategori sangat rendah.. Dari persentase ini terlihat bahwa secara keseluruhan siswa kelas VIII SMP/MTS Kecamatan Sambutan tingkat kemampuan pemecahan masalah sangat rendah dalam kompetensi menghitung keliling dan luas bangun segitiga dan segi empat serta menggunakannya dalam pemecahan masalah.

Pada instrument instrumen nomor 5 diperoleh persentase untuk kompetensi ini yaitu sebesar 5,58\% dengan kategori sangat rendah. Dari persentase ini terlihat bahwa secara keseluruhan siswa kelas VIII SMP/MTS Kecamatan Sambutan tingkat kemampuan pemecahan masalah sangat rendah dalam kompetensi menghitung keliling dan luas bangun segitiga dan segi empat serta menggunakannya dalam pemecahan masalah.

\section{Kompetensi Memahami Sifat-Sifat Sudut yang Terbentuk Jika Dua Garis Berpotongan atau Dua Garis Sejajar Berpotongan dengan Garis Lain}

Untuk kompetensi ini terdapat pada instrument penelitian nomor 4. Pada instrument instrumen nomor 4, diperoleh persentase kompetensi ini yaitu sebesar $41,1 \%$ dengan kategori cukup. Dari persentase ini terlihat bahwa secara keseluruhan siswa kelas VIII SMP/ MTS Kecamatan Sambutan tingkat kemampuan pemecahan masalah cukup dalam kompetensi memahami sifat-sifat sudut yang terbentuk jika dua garis sejajar dan berpotongan dengan garis lain.

Pencapaian kompetensi untuk keseluruhan subjek penelitian adalah sebagai berikut: Untuk kemampuan 
pemecahan masalah secara keseluruhan dari 6 sekolah tersebut dengan jumlah seluruh subjek penelitian sebanyak 270 siswa memiliki rata-rata tingkat kemampuan pemecahan masalah sebesar 29\% dengan persentase masing-masing aspek kemampuan pemecahan masalah: Kemampuan mengidentifikasi masalah dari instrumen sebesar 29,63\% dengan kategori rendah, kemampuan menyusun model pemecahan masalah sebesar $28,33 \%$ dengan kategori rendah, kemampuan memilih strategi pemecahan masalah sebesar 29,74\% dengan kategori rendah, kemampuan sinkron hasil sebesar $30,27 \%$ dengan kategori rendah.

Dari hasil penelitian didapati bahwa banyak siswa yang melakukan kesalahan pada langkah merencanakan penyelesaian masalah dan menyelesaikan masalah. Siswono (2008:35) menyetakan kemampuan siswa terhadap konsepkonsep matematika yang berbeda-beda tingkatannya dapat memicu perbedaan kemampuan siswa dalam memecahkan masalah.

\section{KESIMPULAN}

Berdasarkan hasil analisis data dan pembahasan hasil penelitian, pencapaian kemampuan pemecahan masalah siswa pada kompetensi mengidentifikasi sifatsifat segi empat, segitiga, dan garis adalah rendah dengan persentase $33,5 \%$. Pencapaian kemampuan pemecahan masalah siswa pada kompetensi memahami dan menentukan hubungan dua garis, besar, dan jenis sudut adalah tinggi dengan persentase $66,85 \%$. Pencapaian kemampuan pemecahan masalah siswa pada kompetensi menghitung keliling dan luas bangun segitiga dan segi empat serta menggunakannya dalam pemecahan masalah adalah sangat rendah dengan persentase $\quad 4,52 \%$. Pencapaian kemampuan pemecahan masalah siswa pada kompetensi memahami sifat-sifat sudut yang terbentuk jika dua garis berpotongan atau dua garis sejajar berpotongan dengan garis lain adalah cukup dengan persentase 41,1\%. Dari keseluruhan data mengenai pencapaian kemampuan pemecahan masalah siswa kelas VIII di SMP/MTS Kecamatan Sambutan terhadap kompetensi dasar materi geometri kelas VII adalah rendah dengan persentase $29,49 \%$.

\section{DAFTAR PUSTAKA}

Asmani, J.M. 2011. Tuntunan Lengkap Metodologi Praktis Penelitian Pendidikan. Jogjakarta: DIVA Press.

Bennet, A. B. \& Nelson, Jr.L. 2001. Mathematics for Elementary Teachers: a Conceptual Approach. America: McGraw-Hill.

BSNP. 2006. Standar Kompetensi dan Kompetensi Dasar SMP/MTS. Jakarta: Badan Standar Nasional Pendidikan (BSNP).

Chotimah, N.H. 2014. Pengaruh Model Pembelajaran Generatif (MPG) Terhadap Kemampuan Pemecahan Masalah dan Disposisi Matematis Siswa di Kelas X pada SMA Negeri 8 Palembang. Skripsi. Universitas PGRI Palembang.

Hamalik, O. 2012. Kurikulum dan Pembelajaran. Jakarta: Bumi Aksara.

78 Pencapaian Kemampuan Pemecahan Masalah Matematika Siswa Kelas VIII Dalam Kompetensi Dasar Geometri Kelas VII Di SMP/MTs Kecamatan Sambutan Tahun Ajaran 2015/2016

Nuuri Hanifah - P.M. Labulan - Kukuh 
Isaac, S., \& Michael, W.B. (2003). Handbook in research and evaluation. California: Edits Publishers.

Kohn, E. 2001. Cliffs Quick Reviewtm Geometry: Seri Matematika Keterampilan Geometri. Terjemahan oleh Ervina Yudha Kusuma. 2003. Bandung: CV. Pakar Raya.

Larson, dkk. 2004. Geometry. McDougal Littell: A Houghton Mifflin Company.

Marks, J.L., Purdy, C.R., \& Kinney, L.B. 1965. Teching Elementary School Mathematics for Understanding. America: McGraw-Hill.

Nuharini, D. dan Wahyuni, T. 2008. Matematika Konsep dan Aplikasinya untuk SMP/MTs Kelas VII. Jakarta: Pusat Perbukuan Departemen Pendidikan Nasional.

Susilo, M. J. 2007. Kurikulum Tingkat Satuan Pendidikan: Manajemen Pelaksanaan dan Kesiapan Sekolah Menyongsongnya. Yogyakarta: Pustaka Pelajar.

Suwaji, U. T. 2008. Permasalahan Pembelajaran Geometri Ruang SMP dan Alternatif Pemecahannya . Yogyakarta: Pusat Pengembangan dan Pemberdayaan Pendidikan Tenaga Kependidikan 
Jurnal PRIMATIKA, Volume 7, Nomor 2, Desember 2018

80 Pencapaian Kemampuan Pemecahan Masalah Matematika Siswa Kelas VIII Dalam Kompetensi Dasar Geometri Kelas VII Di SMP/MTs Kecamatan Sambutan Tahun Ajaran 2015/2016

Nuuri Hanifah - P.M. Labulan - Kukuh 